\title{
O Estado como Acionista Minoritário nas Sociedades Privadas
}

\author{
The State as a Minority Shareholder in Private Companies
}

\author{
Pedro de Menezes Niebuhr ${ }^{1}$ \\ Luiz Eduardo Alterburg de Assis ${ }^{2}$ \\ ${ }^{1}$ Universidade Federal de Santa Catarina, Florianópolis, SC, Brasil \\ ${ }^{2}$ Universidade Federal do Paraná, Curitiba, PR, Brasil
}

Resumo: $\mathrm{O}$ artigo analisa o fenômeno da participação minoritária do Estado nas sociedades empresárias. Aborda-se: (i) as principais características das empresas estatais e o que as diferencia das empresas controladas; (ii) a forma como o Estado pode assumir a condição de acionista controlador sem a maioria do capital social e as implicações desse controle no regime jurídico dessas sociedades; (iii) o regime jurídico das sociedades com participação estatal minoritária sob controle privado e as principais causas que justificam a participação estatal desprovida de poder de controle. Conclui-se que a empresa controlada pelo Estado sofre influxo parcial do regime publicístico, eis que o Estado não pode se desvincular, como acionista controlador, dos princípios que regem sua intervenção no domínio econômico. Por outro lado, a participação estatal minoritária não dispensa o Estado de adotar práticas de governança e de controle proporcionais à relevância, à materialidade e aos riscos do negócio.

Palavras-chave: Intervenção do Estado no Domínio Econômico. Empresa Estatal. Empresa Controlada. Empresa Público-Privada. Participação Estatal Minoritária.
Abstract: The article analyzes the phenomenon of minority participation by the State in business societies. It addresses: (i) the main characteristics of State-owned companies and what differentiates them from controlled companies; (ii) the way in which the State can assume the condition of controlling shareholder without a majority of the share capital and the implications of this control in the legal regime of these companies; (iii) the legal regime of companies with minority State participation under private control and the main causes that justify State participation without control power. It is concluded that the company controlled by the State suffers a partial influx from the publicist regime, since the State cannot detach itself, as a controlling shareholder, from the principles that govern its intervention in the economic domain. On the other hand, minority State participation does not exempt the State from adopting governance and control practices proportional to the relevance, materiality and risks of the business.

Keywords: State Intervention in the Economic Domain. State-Owned Company. Controlled Company. Public-Private Company. Minority State Participation.

Recebido em: 15/05/2019

Revisado em: 21/04/2020

Aprovado em: 27/04/2020 


\section{Introdução}

A intervenção direta do Estado no domínio econômico costuma realizar-se por meio de empresas públicas, sociedades de economia mista e suas subsidiárias, todas sob controle acionário da Administração. Ainda que submetidas ao regime jurídico próprio das empresas privadas, as empresas estatais exploradoras de atividade econômica integram a Administração Indireta, sujeitando-se, pois, aos princípios que regem o exercício da função administrativa.

$\mathrm{Na}$ esteira de conglomerados empresariais sob a alçada das empresas estatais, surgiram as sociedades com participação estatal minoritária. De acordo com Rafael Schwind (2017), trata-se de participação do Estado como sócio-empresário, em uma autêntica relação de parceria, de natureza societária, entre os setores público e privado, sem que dessa relação decorra o necessário controle da empresa pelo ente administrativo, ainda que ele disponha de alguns poderes extravagantes.

A Constituição da República não ignorou o fenômeno da participação do Estado em empresas privadas, tampouco a existência de empresas sob o controle estatal que não se qualificam como empresa pública ou sociedade de economia mista; tanto que condicionou a participação estatal nessas sociedades à edição de lei autorizativa. Também a Lei n. 13.303/2016 tratou especificamente do tema, inclusive no que se refere às empresas controladas e às empresas com participação estatal sob controle privado.

Dessa forma, a presente pesquisa visa a identificar as razões que justificam a participação estatal minoritária em sociedades empresárias como instrumento de intervenção do Estado na economia, sob a premissa de que o controle efetivo do Estado sobre essas sociedades, ainda que com mediante participação minoritária, influencia diretamente na definição de seu regime jurídico. 


\section{O Estado Empresário e suas Formas de Atuação}

Interessa ao propósito da presente investigação estabelecer, inicialmente, a distinção entre múltiplas formas de intervenção do Estado no domínio econômico, a saber: (i) por meio de empresas públicas e sociedades de economia mista; (ii) por suas subsidiárias; e (iii) pela participação estatal minoritária em empresas privadas.

\subsection{Empresas Públicas e Sociedades de Economia Mista}

O artigo 173 da Constituição da República dispõe que o Estado só pode atuar diretamente no domínio econômico em circunstâncias excepcionais, vale dizer, somente quando necessário aos imperativos da segurança nacional ou diante de relevante interesse coletivo. Partindo desses pressupostos, o artigo $2^{\circ}$ da Lei n. 13.303/2016 (Lei das Estatais) determina que "[...] a exploração de atividade econômica pelo Estado será exercida por meio de empresa pública, de sociedade de economia mista e de suas subsidiárias". Logo, pelo menos no campo da intervenção direta, só resta ao Poder Público atuar por meio de empresa pública, sociedade de economia mista ou subsidiária. São as chamadas empresas estatais.

$\mathrm{O}$ artigo $3^{\circ}$ da Lei n. 13.303/2016, a seu turno, conceitua a empresa pública como

[...] a entidade dotada de personalidade jurídica de direito privado, com criação autorizada por lei e com patrimônio próprio, cujo capital social é integralmente detido pela União, pelos Estados, pelo Distrito Federal ou pelos Municípios.

O parágrafo único do dispositivo admite a presença de mais de um ente federativo e de outras entidades administrativas no quadro societário da empresa pública, contanto que a maioria de seu capital votante pertença à União. Já a sociedade de economia mista é definida, na forma do artigo $4^{\text {o }}$ da Lei n. 13.303/2016, como:

[...] a entidade dotada de personalidade jurídica de direito privado, com criação autorizada por lei, sob a forma de sociedade anônima, 
cujas ações com direito a voto pertençam em sua maioria à União, aos Estados, ao Distrito Federal, aos Municípios ou a entidade da administração indireta.

A principal diferença entre a empresa pública e a sociedade de economia mista reside no fato de que todo o capital social da empresa pública pertence à Administração Pública, ao passo que, na sociedade de economia mista, constituída necessariamente sob a forma de sociedade anônima, a maioria das ações com direito a voto, embora não a totalidade, encontra-se sob a titularidade do Poder Público.

A distinção não exige maiores digressões, porquanto a própria Lei n. 13.303/2016, reproduzindo o Decreto-lei n. 200/1967, caracterizou a ambas como entidades administrativas dotadas de personalidade jurídica de direito privado com criação autorizada por lei. Sujeitam-se, pois, aos princípios do caput do artigo 37 da Constituição da República e a procedimentos próprios de índole publicística, como a exigência de licitação para contratar bens e serviços (pelo menos para as atividades-meio, conforme se discorrerá adiante), concurso público para a contratação de pessoal e submissão às formas de controle externo da Administração Pública.

Quanto à natureza de sua atividade, a doutrina costuma distinguir as empresas estatais prestadoras de serviços públicos das empresas estatais exploradoras da atividade econômica. A exploração estatal de atividade econômica, por força do inciso II do artigo 173 da Constituição da República, deve respeitar as regras de livre mercado e o regime jurídico próprio das empresas privadas, inclusive quanto aos direitos e às obrigações civis, comerciais, trabalhistas e tributários, sem usufruir de quaisquer privilégios fiscais não extensíveis à iniciativa privada.

Desde logo, é possível antever que as estatais submetem-se a um regime jurídico híbrido, que congrega a um só tempo imposições de direito público e de direito privado. Ao menos quanto à necessidade de licitação pública, ensina Joel de Menezes Niebuhr (2013, p. 50) que “[...] para harmonizar essas duas faces das empresas públicas e sociedades de economia mista, é necessário apartar as suas atividades fim das suas atividades meio". Ele prossegue: 
A atividade fim diz respeito à produção industrial e à comercialização de seus produtos, que se sujeita integralmente ao regime de Direito Privado, por consequência, no que concerne a ela não se configura a obrigatoriedade de licitação pública. Ou seja, essencialmente, a atividade de comprar insumos e comercializar a produção não se sujeita ao regime jurídico administrativo, não seja sujeita à licitação pública. Todavia, no que tange aos meios de aportar a tais finalidades (atividades-meio) incide o regime administrativo, protetor do interesse público, que impõe a obrigatoriedade de licitação pública. Por exemplo, para comprar novo prédio, mobília, computadores, etc. é necessário proceder à licitação pública. (NIEBUHR, 2013, p. 50)

Como se observa, para analisar a incidência do regime jurídico de direito público no âmbito das empresas estatais, é de todo oportuno apartar as atividades-fim das atividades-meio. Daí porque, ao menos nesse aspecto, nos parece ser acertada a conclusão de Vitor Rhein Schirato (2016, p. 99) de que a diversidade de regimes jurídicos aplicáveis às estatais vai além da dicotomia entre serviço público e atividade econômica, de modo que “[...] não haverá um regime jurídico adequado à empresa estatal, mas, sim, uma pluralidade de regimes diversificáveis conforme variam as atividades empreendidas pela empresa em questão". Ao menos, quanto à atividade-fim, pode-se dizer que a incidência do regime de direito privado será mais intensa quanto mais essa atividade é submetida à concorrência e ao livre mercado, ao passo que haverá maior incidência do regime publicístico em atividades exploradas em regime de monopólio ou submetidas a intensa regulação.

Sob essa perspectiva, é inegável que a empresa pública e a sociedade de economia constituem os principais instrumentos para a intervenção direta do Estado no domínio econômico, o que se justifica em razão do seu regime jurídico mais "flexível” que se faz necessário para viabilizar uma efetiva concorrência, da estatal, com as empresas privadas. Nas palavras Rafael Wallbach Schwind (2017), trata-se justamente de mecanismo concebido pelo ordenamento jurídico para viabilizar a empreitada do Estado sem certas amarras de direito público que seriam incompatíveis com a atividade desenvolvida. 
Sem embargo, mesmo essa flexibilidade inerente ao regime jurídico das empresas privadas deve ser explorada com vistas à consecução de um relevante interesse coletivo específico que justifique a intervenção estatal no caso concreto. A exigência de uma finalidade de interesse público, inerente ao exercício de toda e qualquer competência administrativa, não sofre qualquer tipo de mitigação. Ou seja, independentemente da atividade desenvolvida pela empresa estatal, o interesse a ser perseguido permanecesse sendo o interesse público primário, não se admitindo o manejo da estatal para perseguir sua finalidade exclusivamente lucrativa.

\subsection{Empresas Estatais Subsidiárias}

Quando o ordenamento se refere às empresas públicas e às sociedades de economia mista, não raro também alude às suas subsidiárias e controladas. A Constituição da República, a Lei n. 13.303/2016 e o Decreto-lei n. 200/1967 não definem o conceito de subsidiárias, nem trazem qualquer distinção em relação às chamadas empresas controladas. Desses diplomas, pode-se apenas inferir que são empresas integradas submetidas ao controle de outra empresa pública ou sociedade de economia mista, titular da maioria do capital social com direito a voto. Trata-se, pois, de entidades pertencentes à Administração Indireta.

Com efeito, as referências constitucionais às subsidiárias denotam que o legislador constituinte pretendeu sujeitar-lhes ao mesmo regime jurídico das empresas públicas e sociedades de economia mista. É o que se depreende tanto da previsão constitucional de um mesmo Estatuto para regular as empresas públicas, sociedades de economia mista e suas subsidiárias, nos termos do disposto no $\S 1^{\circ}$ do artigo 173 , quanto da exigência de autorização legislativa para a sua criação, na forma dos incisos XIX e XX do artigo 37.

Sob essa ótica, a interpretação mais consentânea com o tratamento constitucional da matéria é aquela mais abrangente que, em paralelo com às empresas públicas e sociedades de economia mista, considera como subsidiárias tanto as empresas que tenham uma entidade da Administração indireta como único acionista, quanto aquelas em que a entidade 
administrativa detém a maioria do capital social com direito a voto ${ }^{1}$, sujeitando todas essas figuras a se submeterem ao mesmo regime jurídico afeto às empresas estatais.

Em vista dessas constatações, afigura-se acertada a definição trazida no inciso IV do artigo $2^{\circ}$ do Decreto Federal n. 8.945/2016, que define como subsidiária, para fins de aplicação da Lei n. 13.303/2016, a “[...] empresa estatal cuja maioria das ações com direito a voto pertença direta ou indiretamente a empresa pública ou a sociedade de economia mista".

\section{O Exercício do Poder de Controle pela Administração Pública nas Sociedades com Participação Estatal Minoritária}

A partir de uma concepção mais abrangente de empresa subsidiária encampada pelo Decreto Federal n. 8.945/2016 - que contempla tanto as chamadas subsidiárias integrais quanto as empresas com participação majoritária de empresa estatal - resta saber se ainda persiste alguma utilidade prática na definição de empresas controladas ou mesmo se existe algum tipo de empresa que seja controlada direta ou indiretamente pelo Poder Público sem enquadrar-se como empresa pública, sociedade de economia mista ou subsidiária.

O legislador constituinte não observou uniformidade no tratamento das chamadas empresas controladas, valendo-se da expressão para designar indistintamente as empresas públicas, sociedades de economia mista e quaisquer outras empresas, subsidiárias ou não, que estejam submetidas ao controle direto ou indireto da Administração Pública², e mesmo, em

\footnotetext{
${ }^{1}$ A rigor, estas últimas também seriam sociedades de economia mista pelo conceito do artigo $4^{\circ}$ da Lei n. 13.303/2016, que considera sociedade de economia mista a companhia cujas ações com direito a voto pertençam em sua maioria a entidade da Administração indireta.

${ }^{2}$ Nesse sentido, o inciso I do artigo 52 da Constituição da República, que prevê a competência do Senado Federal para legislar privativamente sobre "limites globais e condições para as operações de crédito externo e interno da União, dos Estados, do Distrito Federal e dos Municípios, de suas autarquias e demais entidades controladas pelo Poder Público federal"; o inciso II do artigo 163 prevê que a Lei complementar disporá sobre "dívida pública externa e interna, incluída a das autarquias, fundações e demais
} 
caráter residual, as companhias sob o controle estatal que não enquadradas nessas categorias ${ }^{3}$.

A multiplicidade de referências constitucionais para a empresa controlada indica que a expressão se relaciona com a existência de um controle exercido pelo Estado sobre a empresa, o que não exclui que se possa identificar um tipo específico de controlada pelo Estado que não se confunde com empresa pública, sociedade de economia mista e as suas subsidiárias. Por exclusão, seriam empresas controladas stricto sensu aquelas em que o Estado ostenta a condição de acionista controlador sem a titularidade da maioria do capital social com direito a voto. Em suma, é a participação minoritária do Estado, aliada à titularidade do poder de controle, que diferencia essas sociedades das empresas estatais, em que o Estado é controlador por ser proprietário da totalidade ou, ao menos, da maioria do capital social com direito a voto.

A configuração de uma empresa controlada pela Administração com participação estatal minoritária é possível na exata medida em que a propriedade da maioria do capital social com direito a voto não é condição necessária o controle da companhia. Para que se configure a condição de acionista controlador, nos termos do artigo 116 da Lei Federal n. $6.404 / 1976^{4}$, basta que o acionista ou grupo de acionistas detenha a titula-

entidades controladas pelo Poder Público"; o $§ 3^{\circ}$ do artigo 164 trata do depósito em instituições financeiras oficiais das disponibilidades de caixa "dos órgãos ou entidades do Poder Público e das empresas por ele controladas".

${ }^{3} \mathrm{O}$ inciso XVII do artigo 37 da Constituição da República coloca as sociedades controladas ao lado das empresas subsidiárias, ao dispor que "[...] a proibição de acumular estende-se a empregos e funções e abrange autarquias, fundações, empresas públicas, sociedades de economia mista, suas subsidiárias, e sociedades controladas, direta ou indiretamente, pelo poder público".

${ }^{4}$ Eis o teor do artigo 116 da Lei Federal n. 6.404/1976: “Art. 116 Entende-se por acionista controlador a pessoa, natural ou jurídica, ou o grupo de pessoas vinculadas por acordo de voto, ou sob controle comum, que: a) é titular de direitos de sócio que lhe assegurem, de modo permanente, a maioria dos votos nas deliberações da assembléia-geral e o poder de eleger a maioria dos administradores da companhia; e b) usa efetivamente seu poder para dirigir as atividades sociais e orientar o funcionamento dos órgãos da companhia. Parágrafo único. O acionista controlador deve usar o poder com o fim de fazer a companhia realizar o seu objeto e cumprir sua função social, e tem deveres e responsabilidades para 
ridade permanente de direitos de sócio que lhe garantam preponderância nas deliberações da assembleia geral e na eleição dos administradores e que esse poder seja efetivamente exercido na direção da companhia.

Ocorre que a condição minoritária do Estado, por si só, não lhe assegura tamanha preponderância nas deliberações societárias e o poder de eleger a maioria dos administradores. Ainda que o Estado lograsse êxito na eleição da maioria dos administradores, tal circunstância conjuntural não lhe assegura a titularidade permanente dos direitos de sócio. Como anotam Alfredo Lamy Filho e José Luiz Bulhões Pereira (2017, p. 593), "[...] o fato de diversos acionistas votarem no mesmo sentido na Assembleia Geral não configura, por si só, acionista controlador, pois permanente significa contínuo, ininterrupto e constante".

Logo, para que o Estado assuma a condição de acionista controlador com um mínimo de segurança e estabilidade, é preciso que celebre um acordo de acionistas ${ }^{5}$ que efetivamente lhe confira o poder de dirigir as atividades sociais e orientar o funcionamento da companhia através da titularidade de direitos de sócio que assegurem, de modo permanente, a maioria de votos nas deliberações da assembleia-geral e o poder de eleger a maioria dos administradores.

A celebração de acordo de acionistas sobre compra e venda de ações, preferência para adquiri-las, exercício do direito a voto, ou do poder de controle, como é o caso, é prevista no artigo 118 da Lei n. 6.404/1976. Desde que registrado na sede da companhia, o acordo vincula não apenas as partes contratantes, como também a própria companhia, de modo que o voto que o infringir não será computado pelo presidente da assembleia ou outro órgão colegiado de deliberação. Sua oponibilida-

com os demais acionistas da empresa, os que nela trabalham e para com a comunidade em que atua, cujos direitos e interesses deve lealmente respeitar e atender".

5 Ainda segundo Alfredo Lamy Filho e José Luiz Bulhões Pereira (2017, p. 624), "O regime legal do acordo de acionistas na lei brasileira deixa evidente que a organização normativa do cargo de controlador é exclusivamente legal, se o acionista controlador é pessoa natural; mas se o cargo de controlador é exercido por grupo organizado por acordo de acionistas, as estipulações do acordo registrado na companhia integram o seu sistema normativo, organizando o cargo acrescido de fato à estrutura da companhia". 
de perante terceiros, estranhos à companhia, também é possível mediante averbação nos livros de registro e nos certificados das ações.

No âmbito das empresas estatais, a possibilidade da celebração de acordos de acionistas ainda desperta polêmicas. Ao tratar das sociedades de economia mista, Celso Antônio Bandeira de Mello (2014, p. 199) defende que:

Não podem, sob pretexto algum, efetuar acordos de acionistas, por via dos quais fiquem outorgados aos acionistas minoritários poderes que lhes ensejem conduzir ou embargar a livre condução da empresa por parte daqueles que são, "ex vi legis", majoritários, precisamente para terem mãos desatadas no concernente a isto.

Marçal Justen Filho (2015, p. 292), ao seu turno, discorda do referido entendimento, defendendo que:

Não é incompatível com a noção de sociedade de economia mista que haja controle conjunto com sujeitos privados. Assim, é perfeitamente válido que o Estado promova acordo de acionistas com um ou mais particulares, disciplinando o exercício de direito de voto.

De nossa parte, entendemos que não existe maior óbice à formação de acordo de acionistas que limitem o controle do Estado nas empresas estatais, contanto que a avença não promova a completa alienação do poder de controle em favor do particular, alijando o Estado da administração de companhia na qual detém a maioria do capital social com direito a voto. É que a alienação completa do poder de controle estatal importaria em uma espécie de desestatização, o que, se implementado por acordo de acionistas, violaria a finalidade de interesse público retratada em lei autorizativa que, à luz do artigo 173 da Constituição da República, justifica a atuação do Estado por intermédio de empresa estatal.

De toda sorte, nas empresas com participação estatal minoritária, a celebração de acordo de acionistas não encontra os mesmos obstáculos presentes nas subsidiárias e sociedades de economia mista. É que, no caso da participação do Estado como acionista minoritário, ao invés de miti- 
gar o controle estatal, o acordo amplia a presença do Estado no controle da empresa, com a declarada finalidade de resguardar interesse público que justificou a participação estatal, ainda que minoritária. Dito de outro modo, é por meio de acordo de acionistas que pode ser emprestada a essas empresas com participação estatal minoritária a qualificação de empresa controlada, com todos os consectários daí decorrentes.

Aliás, é justamente em razão da possibilidade de aquisição do poder de controle por acordo de acionistas que alguns autores chegaram a defender a revisão do conceito de sociedade de economia mista contemplado no Decreto-lei n. 200/1967, para que também passasse a contemplar as sociedades em que o Estado exerce o controle por força de acordo de acionistas, sem maioria do capital social ${ }^{6}$. Não foi essa, porém, a opção que prevaleceu na Lei n. 13.303/2016, com a manutenção da exigência de participação estatal majoritária no capital social com direito a voto, o que, ao nosso ver, impede que as empresas controladas pelo Estado por acordo de acionistas sejam equiparadas a sociedades de economia mista.

Note-se que, mesmo na participação estatal minoritária, com ou sem controle do Estado, subsiste a exigência de autorização legislativa, vez que o inciso XX do artigo 37 da Constituição da República dispõe que "[...] depende de autorização legislativa, em cada caso, a criação de subsidiárias das entidades mencionadas no inciso anterior, assim como a participação de qualquer delas em empresa privada". A expressão "em cada caso", presente do dispositivo, diz respeito a cada entidade controladora e não a cada entidade controlada. A autorização legislativa poderá estar contemplada na lei que rege a empresa pública ou sociedade de economia mista. Nesse caso, o artigo $8^{\circ}$ do Decreto Federal n. 8.945/2016 exige autorização do Conselho de Administração para cada participação. Com a celebração de acordo de acionistas que assegure ao Estado o poder

\footnotetext{
${ }^{6}$ É a posição de Vitor Schirato (2016, p. 157): "Exatamente assim é que se pode entender que as sociedades que venham a ser constituídas por determinação autorizativa constante de lei e que tenham confluência de capitais públicos e privados e o Estado como acionista controlador, seja de forma exclusiva pela propriedade da maioria das ações com direito de voto, seja de maneira compartilhada por meio de acordo de voto, serão sociedades de economia mista. Não há como identificar na lei elementos que prediquem que o controle deve ser exclusivo".
} 
de controle, as sociedades empresárias com participação estatal minoritária assumem, então, a condição de empresas controladas pela Administração Pública.

No tocante à delimitação de seu regime jurídico, cabe rememorar que todos os atos praticados pela Administração Pública, ainda que sob a égide do direito privado, subordinam-se a determinados preceitos que regem o exercício da função administrativa, sobremodo aos princípios previstos no caput do artigo 37 da Constituição da República. Especificamente no campo da intervenção direta no domínio econômico, deve observar o artigo 173 da Constituição da República, que exige a presença de imperativos da segurança nacional ou a relevante interesse coletivo e impõe às estatais "[...] a sujeição ao regime jurídico próprio das empresas privadas, inclusive quanto aos direitos e obrigações civis, comerciais, trabalhistas e tributários".

Com efeito, a titularidade do poder de controle pelo Estado, ainda que que sem a maioria do capital social com direito a voto, não deixa de refletir o exercício da função administrativa, bem como constitui uma modalidade de intervenção direta no domínio econômico através da técnica empresarial. Ora, se a conduta do acionista controlador deve observar determinados princípios, forçosamente, a direção da empresa controlada também haverá de observar a esses mesmos princípios ${ }^{7}$. Noutros termos, vale dizer que as empresas controladas pela Administração Pública devem observar os princípios que regem a intervenção direta do Estado no domínio econômico não porque sejam empresas estatais, mas porque o seu acionista controlador não pode deixar de observar esses mesmos princípios.

\footnotetext{
${ }^{7}$ Partindo de semelhante compreensão, Vitor Rhein Schirato (2016, p. 60) também considera a relevância do exercício do poder de controle pela Administração na definição do regime jurídico das sociedades com participação estatal minoritária: "o regime jurídico das empresas público-privadas somente será puro de Direito privado, caso não haja controle da entidade pelo Estado. Caso haja tal controle, deverá haver a incidência parcial de um regime de Direito público, preservando-se, porém, a natureza empresarial da entidade. As empresas em questão não podem ser vistas como uma fuga do regime jurídico do Estado, mas, sim, como um instrumento para potencializar melhorias na realização das finalidades públicas".
} 
Entre esses preceitos que subordinam a Administração Pública controladora e, por via transversa, também as empresas controladas, vale destacar os princípios da legalidade, impessoalidade, moralidade, publicidade e eficiência, previstos no caput do artigo 37 da Constituição da República e a necessária persecução do relevante interesse coletivo ou dos imperativos de segurança nacional que justificaram a intervenção estatal e a submissão da empresa controlada pela Administração ao regime jurídico próprio das empresas privadas, inclusive quanto aos direitos e obrigações civis, comerciais, trabalhistas e tributários.

A parcial submissão das empresas controladas ao regime jurídico aplicável à intervenção direta do Estado no domínio econômico deve ser interpretada cum grano salis. O que não se pode admitir é que a Administração Pública se esquive de seu regime jurídico, em uma espécie de fuga para o direito privado através da aquisição de participação minoritária em conjunto com a celebração de acordo de acionistas que lhe assegure o controle da sociedade. Todavia, o exercício do poder de controle pelo Estado não tem o condão de transformar uma empresa privada com participação estatal minoritária numa sociedade de economia mista e nem de submete-la integralmente ao regime jurídico de direito público.

Se por um lado a sociedade com participação estatal minoritária controlada pelo Estado deve respeitar os princípios administrativos, por outro, o Estado não pode deixar de observar as regras que subordinam o exercício do poder de controle da companhia, como a obrigatoriedade de "[...] usar o poder com o fim de fazer a companhia realizar o seu objeto e cumprir sua função social [...]”, prevista no parágrafo único do artigo 116 da Lei n. 6.404/1976, bem como as hipóteses de exercício abusivo do poder de controle, previstas no $\S 1^{\mathrm{o}}$ do artigo 117 do mesmo diploma ${ }^{8}$.

8 “Art. $117 \mathrm{O}$ acionista controlador responde pelos danos causados por atos praticados com abuso de poder. $\S 1^{\circ}$ São modalidades de exercício abusivo de poder: a) orientar a companhia para fim estranho ao objeto social ou lesivo ao interesse nacional, ou levá-la a favorecer outra sociedade, brasileira ou estrangeira, em prejuízo da participação dos acionistas minoritários nos lucros ou no acervo da companhia, ou da economia nacional; b) promover a liquidação de companhia próspera, ou a transformação, incorporação, fusão ou cisão da companhia, com o fim de obter, para si ou para outrem, vantagem indevida, em prejuízo dos demais acionistas, dos que trabalham na empresa ou dos 
Sob essa ótica, não se pode confundir a necessária observância dos princípios que regem a Administração Pública com a equiparação do regime jurídico das empresas estatais e das empresas com participação estatal minoritária, transportando automaticamente para estas últimas toda a legislação aplicável às primeiras, até porque tal equiparação impediria a realização dos interesses jurídicos que fundamentam a intervenção direta do Estado no domínio econômico pela via da participação minoritária no capital social.

Aliás, mesmo em relação às empresas estatais, a mitigação do regime jurídico de direito público deve conformar-se com a realização dos interesses jurídicos que, à luz do texto constitucional, justificam o emprego da técnica empresarial. Tal constatação foi bem sintetizada por Floriano de Azevedo Marques Neto e Juliana Bonacorsi de Palma, em raciocínio que, ao nosso ver, também se aplica às empresas controladas pela Administração Pública:

Firmamos, portanto, nosso entendimento quanto a esse tópico no sentido de que: a) é indesviável a submissão das empresas estatais (como entes da administração indireta que são) aos princípios da administração pública; b) porém, a aplicação desses princípios a essas empresas não há de ser idêntica ao que ocorre com o restante da administração; c) o equilíbrio entre os princípios e os contornos destes deve ser tal que permita a adequação às finalidades da

investidores em valores mobiliários emitidos pela companhia; c) promover alteração estatutária, emissão de valores mobiliários ou adoção de políticas ou decisões que não tenham por fim o interesse da companhia e visem a causar prejuízo a acionistas minoritários, aos que trabalham na empresa ou aos investidores em valores mobiliários emitidos pela companhia; d) eleger administrador ou fiscal que sabe inapto, moral ou tecnicamente; e) induzir, ou tentar induzir, administrador ou fiscal a praticar ato ilegal, ou, descumprindo seus deveres definidos nesta Lei e no estatuto, promover, contra o interesse da companhia, sua ratificação pela assembléia-geral; f) contratar com a companhia, diretamente ou através de outrem, ou de sociedade na qual tenha interesse, em condições de favorecimento ou não equitativas; g) aprovar ou fazer aprovar contas irregulares de administradores, por favorecimento pessoal, ou deixar de apurar denúncia que saiba ou devesse saber procedente, ou que justifique fundada suspeita de irregularidade. $\mathrm{h}$ ) subscrever ações, para os fins do disposto no art. 170, com a realização em bens estranhos ao objeto social da companhia". 
estatal, mormente aquela que atua sob regime de competição; d) negar esse sopesamento importaria em ferir a um só tempo princípios sobremodo relevantes como a legalidade e o interesse público. (MARQUES NETO; PALMA, 2016, p. 74)

Destarte, nem seria razoável a equiparação de regimes jurídicos, pois o acordo de acionistas, que garante o poder de controle do Estado, não tem o condão de legitimar uma reviravolta no regime jurídico da empresa. $\mathrm{O}$ acordo de acionistas é instrumento sujeito a prazo certo ou a condição resolutiva. Quando fixado por prazo indeterminado, pode ser denunciado unilateralmente a qualquer tempo pelos contratantes. Em qualquer caso, com a extinção do acordo e a perda do poder de controle, a sociedade retorna ao seu regime jurídico anterior.

Seguindo esse passo, convém perquirir em que medida os procedimentos adotados na sociedade com participação estatal minoritária se coadunam com os princípios que regem a Administração Pública e, em não havendo essa compatibilidade, cabe adaptar os procedimentos da sociedade empresária na exata proporção que se fizer necessária para resguardar o interesse público primário, sem prejudicar a fluidez de sua atuação empresarial de modo irreversível.

A partir dessa premissa, não nos parece razoável exigir que as sociedades com participação estatal minoritária sob controle do Estado repliquem o regime geral de licitação pública das estatais ou mesmo os regulamentos internos de suas controladoras. Basta que adotem procedimentos internos para assegurar a seleção da proposta mais vantajosa, em atenção aos princípios da impessoalidade, moralidade, igualdade, publicidade, eficiência, economicidade, entre outros. O mesmo se aplica ao regime de contratação de pessoal, que deve assegurar procedimento pautado pela moralidade, isonomia e impessoalidade.

Por outro lado, quanto ao regime de bens, precatórios e de falência, deve-se admitir que o controle exercido pelo Estado não tem o condão de afastar o regime jurídico das empresas privadas, que visam resguardar direitos de terceiros estranhos à sociedade. Aliás, ao menos nesse ponto, sequer o interesse público exige entendimento diverso diante da partici- 
pação estatal minoritária, conquanto esses bens se vinculam a sociedade majoritariamente pertencente a particulares e, via de regra, no âmbito de exploração de atividade econômica em regime concorrencial. São, portanto, bens particulares no exercício regular de atividade econômica. Sua eventual afetação à prestação de serviço público lhes assegura a mesma proteção conferida aos bens pertencentes às concessionárias e permissionárias de serviço público.

O controle externo também é mitigado pela desnecessidade de remessa das contas anuais ao Tribunal de Contas da União, consoante prevê a Súmula n. 75 daquela Corte:

A competência conferida ao Tribunal de Contas da União pelo art. $7^{\circ}$ da Lei n. 6.223, de 14/07/75, não está condicionada à feição jurídica atribuída à entidade fiscalizada, nem à sua criação por lei ou por ato presidencial; tampouco, se restringe à participação acionária direta ou primária da União e entidades da sua administração indireta, compreendendo, ao invés, as chamadas subsidiárias de segundo ou terceiro grau, mas sem obrigatoriedade de remessa das contas anuais quanto às entidades em que houver participação apenas minoritária. ${ }^{9}$

Por fim, cabe anotar que o Tribunal de Contas da União chegou a admitir a contratação direta de empresa controlada em que o Estado detinha participação minoritária pela hipótese de dispensa do inciso XXIII do artigo 24 da Lei n. 8.666/1993 ${ }^{10}$, sob o fundamento de que:

Para fins de aplicação do art. 24, inciso XXIII, da Lei 8.666/1993, entende-se por controlada a empresa em que a União, direta ou indiretamente, detenha a preponderância do poder de controle (seja pela propriedade da maioria do capital social com direito a voto ou pela titularidade

\footnotetext{
${ }^{9}$ Súmula n. 75 do Tribunal de Contas da União, de 25 de novembro de 1976.

10 “Art. 24. É dispensável a licitação: [...] XXIII - na contratação realizada por empresa pública ou sociedade de economia mista com suas subsidiárias e controladas, para a aquisição ou alienação de bens, prestação ou obtenção de serviços, desde que o preço contratado seja compatível com o praticado no mercado".
} 
de direitos de sócio que que lhe asseguram o domínio nas deliberações sociais ou o poder de eleger a maioria dos administradores). ${ }^{11}$

De fato, a aquisição de participação minoritária aliada ao controle da companhia pode se revelar uma boa técnica de descentralização administrativa, com vistas a viabilizar uma forma economicamente mais vantajosa e mais eficiente para a Administração executar suas finalidades. Tal prática, todavia, pressupõe que a sociedade se submeta aos princípios que regem Administração Pública, sua acionista controladora, a fim de que a participação estatal minoritária não se desnature em um subterfúgio para a empresa contratar com a Administração Pública sem licitação e sem se submeter, efetivamente, a princípios administrativos.

\section{Participação Estatal Minoritária nas Sociedades sob Controle Privado}

Na sequência serão analisadas algumas particularidades da participação minoritária sob controle privado.

\subsection{A Participação Minoritária como Modalidade de Intervenção Indi- reta no Domínio Econômico}

A participação do Estado como acionista minoritário em sociedade empresária não pressupõe, necessariamente, a formalização de um acordo de acionistas que lhe assegure o controle da companhia. O Estado pode simplesmente permanecer como acionista minoritário para a consecução de outras finalidades que não exigem o poder de controle ${ }^{12}$.

\footnotetext{
${ }^{11}$ TCU, Acórdão 1.220/2016, Relator: Ministro Bruno Dantas, Órgão Julgador: Plenário, Julgado em 18/05/2016.

12 Para Rafael Wallbach Schwind (2017, p. 424), “[...] o essencial para a caracterização de uma empresa privada com participação estatal é que a preponderância no poder de controle fique em mãos do sócio privado e não do sócio estatal - e não que este último seja necessariamente o sócio minoritário". O autor ainda destaca três características dessas sociedades empresariais: (i) assunção de riscos inerentes ao empreendimento; (ii) utilização de mecanismos privados e busca do lucro; e (iii) não integração à Administração Pública, pelo que o Estado se equipara a um sócio privado qualquer (SCHWIND, 2017).
} 
Não obstante, também nesse caso, o inciso XX do artigo 37 da Constituição da República exige autorização legislativa para a participação em empresa privada. No âmbito das empresas estatais, o artigo $8^{\circ}$ do Decreto Federal n. 8.945/2016 ainda prevê a necessidade de vinculação com o objeto social e de autorização do Conselho de Administração nos casos em que a entidade controladora for empresa pública, sociedade de economia mista ou subsidiária.

Sob o controle privado, essas sociedades não se submetem ao regime jurídico das empresas estatais e sequer podem ser consideradas entidades da Administração indireta. Nas palavras de Marçal Justen Filho (2015, p. 323), "[...] ela não se sujeita a promover concurso público para contratação de empregados e não está obrigada a realizar licitação. Nem sequer será o caso de prestação de contas aos tribunais de contas". Mas ainda assim, adverte o administrativista, “[...] é indispensável que a participação do Estado se traduza em poderes destinados a impedir condutas empresariais incompatíveis com a realização dos interesses estatais que justificaram o aporte de recursos públicos" (JUSTEN FILHO, 2015, p. 323).

A advertência do ilustre administrativista restou contemplada no $\S$ $7^{\circ}$ do artigo $2^{\circ}$ da Lei n. $13.303 / 2016$ e no artigo $9^{\circ}$ do Decreto Federal n. 8.945/2016, que previram a implementação de medidas para fiscalizar a sociedade empresária em que empresa pública, sociedade de economia mista ou subsidiária não detenha controle acionário, por meio de práticas de governança e controle proporcionais à relevância, à materialidade e aos riscos do negócio.

Percebe-se, pois, que a participação estatal em sociedades empresárias sob controle privado não é propriamente uma modalidade de intervenção direta no domínio econômico, já que o Estado não detém a prerrogativa de dirigir a companhia conforme os imperativos da segurança nacional ou relevante interesse coletivo que justificam esse tipo de intervenção.

Nessa hipótese, a intervenção no domínio econômico se dá de forma indireta, através da aquisição de parcela minoritária do capital social que, sem assegurar o poder de controle, possibilita que o Estado influencie nas decisões do controlador ou usufrua de benefícios inerentes à con- 
dição de acionista minoritário que justifiquem o investimento estatal, com vistas a assegurar o interesse público, promover o desenvolvimento de determinados setores e estruturar projetos de infraestrutura, como será melhor delineado no próximo tópico.

\subsection{Algumas Finalidades da Participação Estatal Minoritária nas So- ciedades Empresárias sob Controle Privado}

A participação estatal minoritária nas sociedades empresárias sob controle privado pode se justificar como uma estratégia de fomento, como medida para influenciar na direção de determinadas entidades ( $\mathrm{gol}$ den shares) e para viabilizar a participação estatal em projetos complexos que demandem atuação em parceria com agentes privados.

\subsubsection{Fomento}

Uma das principais finalidades que justificam a participação estatal minoritária em sociedades privadas é o fomento. Como aponta Maria Sylvia Zanella Di Pietro (2009, p. 19), trata-se de o Estado “[...] ajudar, estimular, criar condições para que vários grupos de interesses, representados por entidades particulares, partam à busca de seus próprios objetivos". Ou, como prefere Marcos Juruena Villela Souto (2005, p. 3), trata-se da adesão, por parte dos particulares, a objetivos de interesse público fixados em lei em troca de incentivos estatais. Trata-se, pois, de uma forma de incentivar os agentes econômicos a adotar ações que o Estado julgue adequadas à consecução do interesse público. Bem por isso, a participação estatal minoritária “[...] pode ser enquadrada no conceito de fomento, eis que se trata essencialmente de induzir a iniciativa privada ao desenvolvimento de atividades ao desenvolvimento de atividades socialmente desejáveis" (JUSTEN FILHO, 2015, p. 719).

A depender do caso concreto, a participação estatal pode se revelar mais eficiente que outras modalidades de fomento para favorecer determinadas empresas cujo crescimento seja considerado de interesse público. Alexandre Santos de Aragão (2009, p. 33-68) diferencia essa via de outras modalidades de fomento, conquanto "[...] o Estado assume os riscos do negócio conjuntamente com a iniciativa privada, mas faz jus à 
proporção de eventuais lucros dela decorrentes, bem como da propriedade intelectual das criações realizadas com o seu apoio". O autor traz o exemplo do artigo $5^{\circ}$ da Lei n. 10.973/2004, que autoriza a Administração a participar minoritariamente do capital social de empresas, com o propósito de desenvolver produtos ou processos inovadores que estejam de acordo com as diretrizes e prioridades definidas nas políticas de ciência, tecnologia, inovação e de desenvolvimento industrial.

Outro importante exemplo de fomento do Estado por meio da subscrição minoritária do capital social de sociedade empresária pode ser observado na atuação do BNDES Participações S.A. (BNDESPAR), subsidiária integral do Banco Nacional de Desenvolvimento Econômico e Social (BNDES), cujo objeto social consiste em realizar operações visando à capitalização de empreendimentos controlados por grupos privados, aí compreendida a subscrição e integralização de valores mobiliários e ações, preferencialmente em proporções minoritárias, nos termos dos artigos $4^{\circ}$ e $5^{\circ}$ de seu Estatuto.

Em todos esses casos, como se vê, a participação do Estado como acionista minoritário pode se mostrar mais vantajosa ao interesse público do que outras modalidades de fomento que importam na transferência ou renúncia de bens públicos a fundo perdido, por vezes sem garantias idôneas ou contrapartida em favor do Estado, a exemplo de subvenções, benefícios tributários, financiamentos a juros subsidiados, doação de bens públicos móveis ou imóveis etc.

\subsubsection{Influência na Direção da Sociedade Empresária}

Há casos em que a participação minoritária do Estado é verificada pela manutenção de prerrogativas estatutárias que lhe assegurem a possibilidade de intervir em determinados aspectos da direção da companhia por razões de interesse público, por exemplo, por meio do direito de veto ou de indicação de determinados administradores. É o caso das chamadas ações de classe especial, também conhecidas como golden shares, previstas no artigo $8^{\circ}$ da Lei n. 9.491/1997 (Plano Nacional de Desestatização): 
Sempre que houver razões que justifiquem, a União deterá, direta ou indiretamente, ação de classe especial do capital social da empresa ou instituição financeira objeto da desestatização, que lhe confira poderes especiais em determinadas matérias, as quais deverão ser caracterizadas nos seus estatutos sociais.

O $\S 7^{\circ}$ do artigo 17 da Lei Federal n. 6.404/1976 é ainda mais específico, ao dispor que:

Nas companhias objeto de desestatização poderá ser criada ação preferencial de classe especial, de propriedade exclusiva do ente desestatizante, à qual o estatuto social poderá conferir os poderes que especificar, inclusive o poder de veto às deliberações da assembléia-geral nas matérias que especificar.

Em que pese largamente utilizada no âmbito do Plano Nacional de Desestatização, é plenamente possível a criação dessa categoria especial de ações, como uma classe das preferenciais nas sociedades anônimas particulares não desestatizadas (COELHO, 2004, p. 112), consoante prevê o artigo 18 da Lei n. 6.404/1997:

Art. $18 \mathrm{O}$ estatuto pode assegurar a uma ou mais classes de ações preferenciais o direito de eleger, em votação em separado, um ou mais membros dos órgãos de administração.

Parágrafo único. O estatuto pode subordinar as alterações estatutárias que especificar à aprovação, em assembléia especial, dos titulares de uma ou mais classes de ações preferenciais.

Prerrogativas estatutárias semelhantes também podem ser garantidas ao acionista estatal minoritário através de acordo de acionistas, que, nos termos do artigo 118 da Lei n. 6.404/1976, poderá dispor sobre exercício do direito a voto e poder de controle, conquanto a companhia permaneça sob controle privado.

É interessante notar que os textos normativos não indicam quais prerrogativas poderiam ser asseguradas ao acionista detentor de ações de 
classe especial. A omissão é proposital em face das múltiplas possibilidades. Como anota Mário Engler Pinto Júnior (2013, p. 199):

A extensão do direito de voto reservado ao Estado comporta definição estatutária, podendo consistir na indicação de qualquer número de administradores, desde que respeitada a representação assegurada por lei aos demais acionistas, bem como na exigência de aprovação prévia ou posterior de qualquer deliberação de assembleia de geral.

\subsubsection{Projetos de Infraestrutura}

Determinados projetos de infraestrutura, pelo seu porte e complexidade, exigem um aporte substancial de recursos aliado a conhecimentos técnicos muito específicos, muitas vezes estranhos aos quadros da Administração Pública. Nesses casos, a criação de sociedades com participação estatal minoritária constitui uma modalidade de parceria público-privada lato sensu, que permite a utilização dos recursos, do know how e da gestão potencialmente mais especializada do parceiro privado, sem que a Administração tenha de abrir mão de uma influência significativa na gestão e na fiscalização do empreendimento.

Os arranjos societários criados para a viabilizar esses projetos são normalmente chamados de Sociedades de Propósito Específico (SPEs) ou joint ventures. A sociedade de propósito específico não é uma nova modalidade societária, mas sim uma pessoa jurídica de direito privado, com objeto social limitado e específico. Não há, portanto, nenhuma peculiaridade jurídica que diferencie as SPEs das demais sociedades empresárias com participação estatal minoritária, à exceção da especialidade de seu objeto.

Nas parcerias público-privadas, o artigo $9^{\circ}$ da Lei n. 11.079/2004 prevê a criação, antes da celebração do contrato, de sociedade com capital votante majoritariamente privado, incumbida de implantar e gerir o objeto da parceria. Para Alexandre Santos de Aragão (2013, p. 680), trata-se de modalidade societária que instrumentaliza a remuneração e a partilha dos riscos e que, nas palavras do administrativa, "[...] constituiria um interes- 
sante e seguro (inclusive em razão do avançado estágio de consolidação do Direito Societário) mecanismo de divisão e lucros entre o Estado e o parceiro privado". Ainda sobre o assunto, Egon Bockman Moreira (2010, p. 108) destaca as vantagens desse modelo na estruturação de projetos de concessão:

Ao conjugar a tomada de recursos à propriedade dos ativos financiados, a SPE permite a instituição do ciclo vital do projeto concessionário, imputando-se a dívida aos seus próprios resultados. Depois, essa separação patrimonial torna o projeto mais atrativo e confiável. Como a SPE conduzirá exclusivamente um determinado projeto, o que for nela aportado se destina exclusivamente a ele. Por outro lado, ela permite que se institua espécie de partilha de riscos entre aqueles que a instituíram e os investidores que nela aportam valores. Na medida em que o investidor aceita ser pago por meio de resultados, assume o risco - ao lado daqueles que constituíram a SPE - derivado da consecução do projeto.

Nos setores de petróleo e gás também não é incomum a criação de SPEs com participação de subsidiárias da Petrobrás para fins de construção e operação de dutos, terminais marítimos e embarcações para transporte de petróleo, seus derivados e gás natural, conforme preveem os artigos 64 e 65 da Lei n. 9.478/1997. Nas concessões aeroportuárias, o modelo das SPEs com participação minoritária da Infraero foi utilizado para garantir o recebimento de dividendos e fortalecer a empresa pública, conforme restou explicitado no Acórdão n. 1.865/2016, do Tribunal de Contas da União ${ }^{13}$. Como último exemplo, vale mencionar a aquisição

13 “[...] 42. A Infraero, antiga operadora dos aeroportos concedidos, passou a ser sócia das concessionárias (com exceção do ASGA) a fim de que ficasse assegurado à empresa pública o recebimento de dividendos - em substituição às receitas até então auferidas com os aeroportos - visando estabelecer compensações baseadas em sistema de subsídio cruzado entre aeroportos superavitários e deficitários ainda operados por essa empresa pública, com vistas a promover a universalização do sistema. 43. Também conta como motivação para a inserção da Infraero nessas SPE a intenção do fortalecimento da gestão da empresa estatal, permitindo-lhe extrair das SPE em que participa novas formas de maximizar resultados de maneira mais eficiente e, consequentemente, aplicar tais conhecimentos assimilados na operação dos demais aeroportos de sua rede. Por último, 
de participações pelo Banco do Brasil e pela Caixa Econômica Federal, inclusive com a constituição de SPEs com sociedades do ramo da construção civil, para a execução de empreendimentos imobiliários, conforme prevê o artigo $3^{\circ}$ da Lei n. 11.908/2009.

\section{Conclusão}

A participação minoritária no capital social das sociedades empresárias é instrumento à disposição do Estado para atender a diversas finalidades de interesse público e, principalmente, como forma de intervenção direta e indireta no domínio econômico.

A participação estatal minoritária é um meio de intervenção direta no domínio econômico quando o Estado exerce o controle da companhia através de um acordo de acionistas que lhe assegure poderes para dirigi-la em conformidade com o relevante interesse coletivo ou imperativo da segurança nacional que justifique esse tipo de atuação. Nesse caso, a empresa controlada haverá de submeter-se, ainda que parcialmente, aos princípios que regem a Administração Pública, conformando esses princípios à prática empresarial para não comprometer a realização do interesse público que reclama o emprego da técnica empresarial.

Já a participação estatal minoritária desprovida de acordo de acionistas, como instrumento de intervenção indireta no domínio econômico, não altera o regime jurídico da sociedade sob controle privado, mas exige o Estado adote práticas de governança e controle proporcionais à relevância, à materialidade e aos riscos do negócio do qual é partícipe. A despeito da ausência de controle estatal, é certo esse tipo de participação permanece como um meio eficaz para atingir outras finalidades não menos afetas ao interesse público, como a atividade de fomento, a influência em decisões empresariais de relevância nacional e a partilha de riscos e resultados em projetos de infraestrutura.

foi justificada a existência de interesse público da presença da União nesses aeroportos, identificados como estratégicos ou de especial relevância para o interesse público [...]" (TCU, Acórdão n. 1865/2016, Órgão Julgador: Plenário, Julgado em 20/07/2016). 


\section{Referências}

ARAGÃO, Alexandre Santos de. Direito dos serviços públicos. 3. ed. Rio de Janeiro: Forense, 2013.

ARAGÃO, Alexandre Santos de. Empresa público-privada. Revista dos Tribunais, [S.l.], v. 890, p. 33-68, dez. 2009.

BANDEIRA DE MELLO, Celso Antônio. Curso de direito administrativo. 32. ed. São Paulo: Malheiros, 2014.

CÂMARA, Jacintho Arruda. O lucro nas empresas estatais. Revista de Direito Administrativo Econômico (REDAE), Salvador, Instituto de Brasileiro de Direito Público, no 30, maio-junho-julho, 2012.

COELHO, Fábio Ulhoa. Curso de direito comercial. 7. ed. São Paulo: Saraiva, 2004. v. 2.

DI PIETRO, Maria Sylvia Zanella. Parcerias na Administração Pública. 7. ed. São Paulo: Atlas, 2009. p. 19.

JUSTEN FILHO, Marçal. Curso de direito administrativo. 11. ed. São Paulo: Revista dos Tribunais, 2015.

LAMY FILHO, Alfredo; PEREIRA, José Luiz Bulhões. Direito das companhias. 2. ed. Rio de Janeiro: Forense, 2017.

MARQUES NETO, Floriano de Azevedo; PALMA, Juliana Bonacorsi. Empresas estatais e parcerias institucionais. RDA - Revista de Direito Administrativo, Rio de Janeiro, v. 272, p. 59-92, maio-ago. 2016.

MOREIRA, Egon Bockman. Direito das concessões de serviço público: inteligência da lei 8.987/1995. São Paulo: Malheiros, 2010.

MOREIRA NETO, Diogo de Figueiredo. Curso de direito administrativo: parte introdutória, parte geral e parte especial. Rio de Janeiro: Forense, 2005.

NIEBUHR, Joel de Menezes. Dispensa e inexigibilidade de licitação. 4. ed. Belo Horizonte: Fórum, 2015.

NIEBUHR, Joel de Menezes. Licitação pública e contrato administrativo. 3. ed. São Paulo: Fórum, 2013. 
PINTO JÚNIOR, Mário Engler. Empresa estatal: função econômica e dilemas societários. 2. ed. São Paulo: Atlas, 2013.

SCHIRATO, Vitor Rhein. As empresas estatais no direito administrativo econômico atual. São Paulo: Saraiva, 2016.

SCHWIND, Rafael Wallbach. O Estado acionista: empresas estatais e empresas privadas com participação estatal. São Paulo: Almedina, 2017. SOUTO, Marcos Juruena Villela. Direito Administrativo das parcerias. Rio de Janeiro: Lumen Juris, 2005. p. 3.

Pedro de Menezes Niebuhr é professor nos Programas de Graduação e PósGraduação em Direito da Universidade Federal de Santa Catarina. Doutor em Direito pela Pontifícia Universidade Católica do Rio Grande do Sul, com estágio de doutoramento (CAPES) na Universidade de Lisboa. Mestre em Direito pela Universidade Federal de Santa Catarina. Advogado.

E-mail: pedro.n@ufsc.br

Endereço profissional: Universidade Federal de Santa Catarina, Centro de Ciências Jurídicas Campus Universitário, s/n, Trindade, Florianópolis, SC. CEP: 88040-900.

ORCID: https://orcid.org/0000-0003-1185-6173

Luiz Eduardo Alterburg de Assis é doutorando em Direito pela Universidade Federal do Paraná. Mestre em Direito pela Pontifícia Universidade Católica de São Paulo. Advogado.

E-mail: luizeduardo@mnadvocacia.com.br

Endereço profissional: Universidade Federal do Paraná, Rua XV de Novembro, n. 1.299, Centro, Curitiba, PR. CEP: 80060-000.

ORCID: https://orcid.org/0000-0002-3633-1544 